KS. JOACHIM NOWAK

\title{
KRYZYS MIGRACYJNY W NIEMCZECH I JEGO SKUTKI
}

Kryzys migracyjny został zauważony w Niemczech już w 2005 roku, obecnie odnosi się go do problemów i wyzwań dla społeczeństwa, związanych z przyjazdem do Niemiec ponad miliona uchodźców i migrantów w latach 2015 i 2016. Traktuje się go jako część szerzącego się na skalę europejską kryzysu związanego z uchodźctwem. W Niemczech coraz silniej uwidacznia się tendencja do dzielenia imigrantów na przybyłych z terenów objętych wojną, czyli Iraku, Syrii i Afganistanu oraz na tych, których do ucieczki zmusiła sytuacja materialna. Ci drudzy przybyli przede wszystkim z państw zachodniobałkańskich: Serbii, Czarnogóry, Bośni i Hercegowiny, Kosowa, Albanii i Macedonii. Ludzie, którzy z powodu wojny musieli uciekać, w Niemczech otrzymują pomoc, ponieważ niemieckie społeczeństwo tego chce ${ }^{1}$, ponieważ współczucie i, co za tym idzie, okazanie miłości drugiemu człowiekowi jest wpisane w chrześcijański obraz człowieka.

\section{PRZYCZYNY KRYZYSU MIGRACYJNEGO}

Kiedy chcemy mówić o „kryzysie uchodźców”2 jako zjawisku, musimy przede wszystkim przyjrzeć się kryzysowi uchodźców, którzy zostali zmuszeni do ucieczki z własnej ojczyzny. Przyczyn ucieczki ${ }^{3}$ w pierwszym rzędzie należy szukać w trudnej sytuacji rodzimych krajów uchodźców, w których od dawna pogłębia się kryzys humanitarny, mimo niesionej przez inne państwa pomocy; na przykład

Por. N. Kermani, Wer ist wir. Deutschland und seine Muslime. Mit der Kölner Rede zum Anschlag auf Charlie Hebdo, Verlag C.H. Beck oHG, München 2016, s. 55-69.

2 Por. J. Holtkamp, Flüchtlinge und Asyl. Herausforderung-Chance-Zerreißprobe, Lahn-Verlag, Kevelaer 2016, s. 9-14.

3 Por. Ins Offene. Deutschland, Europa und die Flüchtlinge. Die Debatte, red. J. Spahn, Verlag Herder GmbH, Freiburg im Breisgau 2015, s. 15-16. 
Niemcy w ramach Światowego Programu Żywnościowego ONZ (Welternährungsprogramm der Vereinten Nationen - WFP) w połowie finansują wyżywienie blisko 5,5 mln potrzebujących w obozach uchodźców w Syrii. Tym samym wola oddalenia się od własnego kraju staje się na tyle silna, że powstaje decyzja o powzięciu ryzyka związanego z ucieczką. Uchodźcy znajdują schronienie najpierw w sąsiednich krajach. Te jednak należą do gospodarczo najsłabszych w rankingu światowym. Napływ uchodźców rozwiązuje lub pogłębia w nich społeczne i polityczne napięcia. Zaostrzać kryzys może przemieszczanie się uchodźców w państwach tranzytowych, które nie dysponują niezbędną infrastrukturą mogącą zagwarantować w krótkim czasie ochronę, opiekę i nocleg nowo przybyłym. Również w krajach docelowych taka sytuacja może zaistnieć jako kryzysowa.

Należy poczynić rozróżnienie między liczbą uchodźców i migrantów w ogólnym rozrachunku a liczbą ubiegających się o azyl. Jeśli na rok 2015 przypada milion uchodźców, to ich liczbę w stosunku do całej społeczności Unii Europejskiej szacuje się na 0,2 proc. $^{4}$ Prognoza gospodarcza Komisji Europejskiej z jesieni 2015 roku zakładała, że w roku 2016 liczba uchodźców wzrośnie do 1,5 mln, a w 2017 spadnie do 0,5 mln. Warto zauważyć, że od 1990 roku w UE wnioski dotyczące azylu były składane przede wszystkim w bogatych krajach europejskich. Większość wniosków o azyl wystawiono w latach 90. w Niemczech. W 1992 roku było to 440 tys. wniosków, czyli 79 proc. wszystkich wniosków z Unii Europejskiej. Niemcy znajdowały się na trzecim miejscu w relacjach do rodzimej społeczności. Do tego dochodziła także jeszcze wzrastająca liczba repatriantów, która opowiadała się za sprowadzeniem się do Niemiec ${ }^{5}$. Również po zawarciu kompromisu dotyczącego azylantów w maju 1993 Niemcy nadal należały do ważnych docelowych krajów UE. W roku 2011, wraz ze wzrostem napływu uchodźców z Syrii w liczbie ponad 150 tys., Niemcy stały się krajem przyjmującym najwięcej uchodźców wśród innych krajów przemysłowych. 30,6 proc. wszystkich wniosków o azyl dotyczy Niemiec, co czyni je głównym celem przybywających do UE uchodźców. W ramach programu pomocy humanitarnej kraje udzieliły schronienia 37 tys. potrzebującym. To oznacza, że rząd Niemiec ogarnął opieką więcej niż jedną trzecią wszystkich syryjskich uchodźców. Jeśli państwa pierwszego kontaktu nie będą odpowiednio wspierane, będą odmawiać zrealizowania wspólnie wypracowanych ustaleń, uchodźcy będą poszukiwać dalej.

4 Por. S. Luft, Die Flüchtlingskrise. Ursachen, Konflikte, Folgen, Verlag C.H. Beck oHG, München 2016, s. 22-26.

5 Tamże, s. 22-23. 


\section{SYTUACJA MIGRANTÓW}

\subsection{Sytuacja w miejscach zakwaterowania}

Po przyjrzeniu się raportowi z Monachium można stwierdzić, że w wielu miejscach zamieszkiwanych przez uchodźców dochodziło do wyraźnych przejawów agresji muzułmanów przeciwko chrześcijanom: obelg, gróźb i przemocy. Najgorzej traktowani byli muzułmanie, którzy przyjęli wiarę chrześcijańską; ci wielokrotnie byli bici ${ }^{6}$. Problem stanowiła sama dostępność miejsc noclegowych dla ubiegających się o azyl, które w prawie wszystkich niemieckich landach do początku 2016 roku były zajęte. 1 października 2015 roku w Hamburgu uchwalono ustawę, która umożliwiała konfiskatę opuszczonych budynków pod warunkiem, że będą przeznaczone na mieszkania dla uchodźców. Te ustalenia nie dotyczyły mieszkań prywatnych ${ }^{7}$. W Dolnej Saksonii przyjęto wiele zmian w ustawie, aby przed zimą 2015/2016 szybciej i bez zbędnej biurokracji móc stworzyć nowe lokale dla przybywających ${ }^{8}$. W Nadrenii Północnej-Westfalii w listopadzie 2015 roku zaadaptowano - według oszacowań Krajowego Związku Sportowego Nadrenii Północnej-Westfalii - 300-400 hal sportowych na miejsca noclegowe9 Natomiast 5 kwietnia 2016 roku Krajowy Związek Sportowy w Berlinie zażądał natychmiastowego przywrócenia właściwego funkcjonowania tych hal w celu realizacji zajęć sportowych w szkołach oraz związkach sportowych ${ }^{10}$.

Należy zwrócić uwagę na to, że w jeszcze niezamieszkałych budynkach przeznaczonych dla uchodźców były rozniecane pożary, aby ci nie mogli się tam wprowadzić. W Malterdingen w Badenii-Wirtembergii doszło do zalania wodą takiego budynku. W Hesji jeden z lokali został ostrzelany z broni pneumatycznej przez nieznane osoby. W Freital w Saksonii prawicowi ekstremiści zaatakowali miejsce zamieszkania uchodźców. Co więcej, wsparcie okazali im mieszkańcy, określający się jako „wojsko narodowe”. Nie tylko w nowych landach istnieje nienawiść do obcokrajowców, jak pokazuje przypadek w Hesji. Tam jedno z takich mieszkań wybrudzono i obrzucono świńskimi głowami. Ponadto pojawiły się incydenty z udziałem neonazistów. Tłuczone są szyby w oknach, dochodzi nawet do gróźb morderstwa. Polityka zarówno w Europie, jak i w Niemczech ignorowała

6 Wo in Deutschland Christen verfolgt werden, w: www.zeit-online.de 29.7.2014 (15.8.2014); Verfolgt in Deutschland, w: www.welt-online.de 27.9.2015 (15.10.2015).

7 Gesetz zur Flüchtlingsunterbringung! Hamburg beschließt Beschlagnahme von Immobilien, w: www.spiegel-online.de 2.10.2015 (13.11.2015).

8 M. Thomas, Land lockert Bauvorschriften für Flüchtlingsheime, w: www.hannoverscheallgemeinezeitung.de 11.11.2015 (15.12.2015).

9 A. Himmelrath, Erstaufnahme in Turnhallen: Immerhin winterfest, w: www.spiegel-online.de 18.11.2015 (13.12.2015).

10 F. Bachner, Notquartiere für Flüchtlinge in Berlin: Funktionäre fordern Räumungsplan für Sporthallen, „Der Tagesspiegel“ 6.4.2016, s. 8. 
wzrastającą liczbę uchodźców. Tym samym przeoczono konieczność przygotowania rodzimej ludności na przybycie tak dużej liczby obcych kulturowo ludzi w krótkim czasie. Niektórzy komentatorzy przypuszczają, że kryje się za tym jakaś kalkulacja.

\subsection{Stanowisko prawa pracy}

Ubiegających się o azyl obowiązuje przez pierwsze trzy miesiące absolutny zakaz zatrudnienia. Dopiero po upływie tego czasu ubiegają się o pracę. Agencja pracy zabiega jednak o wprowadzenie niebieskiej karty, szczególnie dla dobrze wykształconych uchodźców, co pozwoliłoby szybciej podjąć jakieś zajęcie. Sprawa ta uzyskała jednak niskie poparcie polityczne. Idąc dalej, od 2016 roku rząd nie chce umieszczać uchodźców w statystykach dotyczących rynku pracy, natomiast w ramach współpracy pomiędzy Federalnym Urzędem do Spraw Emigrantów i Uchodźców a agencjami pracy nadal próbuje zapewnić im wsparcie w poszukiwaniu zatrudnienia. Mimo to, według danych północnoniemieckiej Stacji Radiowej (Norddeutscher Rundfunk) z sierpnia 2016 roku, co najmniej 100 tys. przybyłych do Niemiec od 2015 roku skorzystało z nielegalnych form zatrudnienia. Inne szacunki mówią natomiast, że praca blisko 50 proc. $z$ nich nie jest zalegalizowana ${ }^{11}$. W sprawie przybycia wykwalifikowanych pracowników z krajów Trzeciego Świata w ostatnich latach podjęto wiele dobrych ustaleń. Są one zazwyczaj materialnie wystarczające, ale też skomplikowane, niejasne i mało praktyczne dla samych zainteresowanych. Należy przy tym zauważyć, że niewielu uchodźców biegle posługuje się językiem niemieckim. Poza tym poziom ich kwalifikacji jest poniżej przeciętnej w porównaniu z ludnością miejscową. We wrześniu 2015 roku ministerstwo edukacji przeznaczyło pakiet środków na kształcenie i rozwój zawodowy - 130 mln euro „,na następne lata” - który miał służyć „,przyswojeniu języka niemieckiego, rozpoznaniu kompetencji i potencjału uchodźców oraz integracji w kształceniu i zdobywaniu zawodu"12. Do wyjątków zalicza się przypadki np. wykształconych lekarzy z Syrii. Nawet jeśli poziom kwalifikacji uchodźców jest wysoki, nie mówi on jeszcze nic o perspektywach zawodowych w Niemczech. Warto dodać, że pierwsze doniesienia agencji pracy w ramach programu „Early Intervention" są alarmujące. Średnia gotowość uchodźców do zaangażowania się w rynek pracy plasuje się na poziomie 10 proc. Szerokie pole ogólnej polityki pracy i jej metody zamykają w zasadzie migrantów jako grupę docelową i stanowią właściwie strukturalną politykę integracyjną.

${ }^{11}$ Ch. Heinzle, E. Weydt, Tausende Flüchtlinge als Schwarzarbeiter ausgebeutet, w: www.weltonline.de 30.8.2016 (30.9.2016).

12 Flüchtlinge durch Bildung integrieren, w: www.bundesministeriumfuerbildungundforschung.de 30.9.2015 (30.10.2015). 


\section{POLITYKA INTEGRACYJNA}

Politolog Dietrich Thränhardt w opracowaniu naukowym przygotowanym dla fundacji Bertelsmanna dochodzi do wniosku, że integracja jest kluczową potrzebą społeczeństwa niemieckiego. Żąda on: kursów językowych od początku dla wszystkich wykazujących chęć pozostania w Niemczech; wczesnego ukierunkowania w perspektywach zawodowych i przyjęcia przez agencje pracy jednolitego systemu działania; przydziału pracy uchodźcom koordynowanego przez pośrednictwo pracy, aby ci w swoich regionach mieli dobrą możliwość zatrudnienia; wczesnego wejścia w nową sytuację mieszkaniową; informowania miejscowej ludności o przyjęciu uchodźców; współpracy parafii i społeczności cywilnej ${ }^{13}$. Sabatina James ostrzega tymczasem przed ,naiwnym optymizmem integracyjnym”, odnosząc się do dotychczasowych doświadczeń z dziesiątkami tysięcy uchodźców wojennych z Libanu w latach 90., których integracja była zupełnie nieudana. To nie zachęca do założenia, że tym razem asymilacja wielu więcej muzułmańskich uchodźców z krajów arabskich miałaby się udać ${ }^{14}$. Politolog Hamed Abdel-Samad podaje w wątpliwość to, że większość muzułmańskich uchodźców chce się w ogóle integrować ${ }^{15}$.

Integracja przebiega w wieloraki sposób i wpływają na nią różne czynniki związane $\mathrm{z}$ migracją ${ }^{16}$. To, na razie chwilowo ograniczone, pozwolenie na pobyt dla migrantów zarobkowych różni się znacząco w warunkach i skutkach dla integracji od statusu migrantów zawierających związek małżeński lub repatriantów, którzy od początku posiadali prawną przynależność do społeczeństwa i państwa. Podstawowe znajomości procesów migracji są niezbędnym warunkiem zrozumienia integracji. Udana integracja oznacza przyjęcie drugiego człowieka takim jaki jest $^{17}$. Integracja potrzebuje dobrych warunków ogólnych. Należy jednak zaakceptować to, że istnieją pewne ograniczenia $\mathrm{w}$ integracji. $\mathrm{Z}$ reguły dotyczą one kwestii osobistych, politycznych lub religijnych, które uniemożliwiają w niektórych przypadkach integrację.

13 Die Arbeitsintegration von Flüchtlingen in Deutschland, w: www.bertelsmann-stiftungstudie2015. de (13.12.2015).

14 T.-R. Stoldt, Diese Frau greift den deutschen Islam frontal an, w: www.welt-online.de 30.10.2015 (13.11.2015).

15 Die meisten, die herkommen, denken nicht an Integration, w: www.welt-online.de 30.09.2015 (13.10.2015).

16 Por. F. Heckmann, Integration von Migranten. Einwanderung und neue Nationenbildung, Springer-Verlag, Wiesbaden 2015, s. 15; S. Leimgruber, Feinde oder Freunde. Wie können Christen und Muslime miteinander umgehen, Lahn-Verlag, Kevelaer 2008, s. 10.

17 Por. S.K. Samir, 100 Fragen zum Islam. Warum wir die Muslime nicht fürchten müssen, Sankt Ulrich Verlag, Augsburg 2009, s. 147-152. 


\section{REAKCJA NIEMIECKIEGO SPOLECZEŃSTWA NA SYTUACJE MIGRANTÓW}

\subsection{Kultura powitania i zaangażowanie $w$ wolontariat}

W kryzys uchodźctwa w 2015 roku zaangażowało się wielu wolontariuszy, współpracując z organizacjami charytatywnymi ${ }^{18}$. Zaangażowanie wolontariatu jest tak duże jak latem 2015 r. Ale w medialnym odbiorze koncentrowano się jednostronnie na kulturze powitania, a dzisiaj bardziej na przerażających wydarzeniach. Niemieckie obywatelki i niemieccy obywatele oraz odpowiedzialni politycznie wstawili się za tym, że kraj nie pozostawi prześladowanych ludzi znajdujących się w trudnej i wyjątkowej sytuacji humanitarnej. Miała miejsce ponad tysiąckrotna pomoc, zaangażowanie w wolontariat i niewiarygodny duch obywatelski.

Nie tylko dla monachijskiego społeczeństwa drugi weekend września 2015 r. zostanie jeszcze na długo w pamięci. Tysiące uchodźców przybyło w pociągach i autobusach z Węgier przez Austrię do stolicy Bawarii. Setki wolontariuszy przyjmowało uchodźców i zatroszczyło się o ich wyżywienie. Zorganizowano punkty zbiórki odzieży i magazyny mebli. Część z nich została przepełniona z powodu tak dużej liczby podarowanych rzeczy. Uchodźców wspomagały różne związki, fundacje i inne chętne grupy wsparcia. Pomagającym w kościołach i Caritasie nasuwało się jednak pytanie o to, czy uda się utrzymać na takim poziomie gotowość niesienia pomocy i empatię przez kolejne miesiące? Co się stanie, jeśli zaangażowanie zmaleje i przerodzi się w złość lub wściekłość? Nikt nie może przewidzieć, jak długo będzie trwać ta nietypowa chęć niesienia pomocy dla rzeszy uchodźców. Wolontariat wymaga dyspozycyjności, czasu, osoby w niego się angażujące w pewnym momencie mogą zostać przytłoczone natłokiem zajęć związanych z pomocą uchodźcom. Mogą w końcu poczuć, że osiągnęli kres swoich możliwości. Ponieważ społeczne zaangażowanie wolontariuszy koncentruje się z reguły wokół środowiska, w którym żyją, często odczuwają oni trudność w zdystansowaniu się do problemów, z którymi spotykają się, przebywając z uchodźcami. Znalezienie właściwej drogi między pełnym zaangażowaniem przynoszącym konkretne efekty a profesjonalnym dystansem nie jest wcale łatwe.

\subsection{Ksenofobiczne zamieszki}

Płonące kwatery uchodźców i hasła „Niemcy dla Niemców” wywołują strach nie tylko w politykach. W Niemczech tworzą się skrajnie prawicowe i radykalne ugrupowania, które aktywnie występują przeciwko uchodźcom. Na podstawie

18 Freiwillige sind unentbehrlich, w: www.sueddeutsche.de 23.9.2015 (20.10.2015). 
badań naukowych stwierdzono, że niemieckie społeczeństwo, o czym już wspomniano, nie zostało wystarczająco dobrze przygotowane na przyjęcie tak dużej liczby osób. Doprowadziło to do różnych obaw, m.in. o utratę dotychczasowych miejsc pracy, rozniecało uprzedzenia i niszczyło chęć niesienia pomocy. Pojawił się ogromny problem z rozróżnieniem, kto przybył z powodu biedy, a kto uciekł przed wojną. Dlatego wszystkich traktuje się ogólnie jako uchodźców lub migrantów.

Kto się zajmuje zagadnieniem imigracji, nieuchronnie staje w obliczu pytania, czy systemy społeczne podołają napływowi tylu ludzi. Wysuwane są argumenty, że system socjalny jest obecnie poważnie obciążony. Wiele gmin stoi przed zbliżającą się ruiną finansową. Sugeruje się, że jeśli Niemcy nadal będą przyjmować tak dużo imigrantów, doprowadzi to do finansowego upadku państwa. Tego typu przewidywania wywołują wzrost niepokoju w społeczeństwie, czego przejawem są ataki na domy dla uchodźców, których według Federalnego Urzędu Policji Kryminalnej (Bundeskriminalamt - BKA) do końca sierpnia 2015 roku odnotowano $335^{19}$. Federalny Urząd Ochrony Konstytucji (Bundesamt für Verfassungsschutz) obawia się, że może powstać na nowo zorganizowany terroryzm prawicowy $^{20}$, posługujący się przede wszystkim nienawistnym językiem, pełnym przemocy i obelg. Protesty i zamieszki o ksenofobicznym charakterze w Freital, Heidenau i Dresden, ale i akty przemocy w stosunku do Henriette Reker czy też protesty w Clausnitz zwróciły uwagę mediów na skalę tego problemu. Od stycznia do grudnia 2015 roku według danych Federalnego Urzędu Policji Kryminalnej popełniono 1005 czynów karalnych w mieszkaniach osób ubiegających się o azyl. W 92 przypadkach były to podpalenia. Dla porównania w 2004 roku zarejestrowano 6 takich zdarzeńn ${ }^{21}$.

\section{REAKCJA MEDIÓW NA SYTUACJĘ MIGRANTÓW}

W ubiegłych latach media, nie tylko niemieckie, niestety zaniedbały kwestie związane z uchodźcami. W radio i telewizji przez długi czas temat uchodźców był marginalizowany. Dzięki procesom globalizacyjnym, dużą rolę w tym zakresie odgrywają media społecznościowe, wzrosło jednak zainteresowanie tym problemem. Wojna w Afganistanie, śmierć w Afryce lub na Morzu Śródziemnym, mimo tego, że mają miejsce w odległych zakątkach świata, potrafią silnie oddziaływać

19 Der Tag: Anschläge auf Flüchtlingsheime nehmen drastisch zu, w: www.ntv.de 28.9.2015 (13.10.2015).

20 Kriminalität: Furcht vor neu organisiertem Rechtsterrorismus, w: www.zeit-online.de 28.8.2015 (13.9.2015).

21 Gewaltwelle: BKA zählt mehr als tausend Attacken auf Flüchtlingsheime, w: www.spiegel-online.de 28.1.2016 (13.2.2016). 
na siedzących w wygodnych fotelach mieszkańców Europy. Tak samo dzieje się w przypadku ludzie z krajów zagrożonych wojną, do których również mogą trafiać obrazy z naszego wygodnego życia.

Deutsche Welle relacjonuje wszechstronnie, od lat stosując międzynarodową perspektywę. W programach przetwarza się informacje w 30 językach, także w językach uchodźców. Ciągły kontakt z odbiorcami z kręgu arabskiego i z Afryki pozwolił wcześnie wystosować i rozwinąć odpowiednią ofertę dostosowaną do potrzeb nowo przybyłych. Przygotowano odpowiednie programy, tematy tygodnia, dostosowano media społecznościowe. W Akademii Deutsche Welle są prezentowane kursy języka niemieckiego, które spotykają się z dużym zainteresowaniem. Dzięki temu stacja zyskała wyśmienitą opinię w regionach dotkniętych przez kryzys migracyjny.

Debatę o uchodźcach w Europie bardziej niż informacje podawane w różnych środkach przekazu kształtowały obrazy i filmy o nich traktujące. Jeśli ktoś zastanawia się, jak symbolicznie przedstawić ryzyko i grozę wiążące się z ucieczką, z pewnością przyjdzie mu na myśl widok martwego małego Aylana z Syrii leżącego na plaży w Bodrum. To zdjęcie obiegło świat, wywołując konsternację i współczucie. Jednak dla mediów celem nadrzędnym nie powinno być pokazywanie czy wywoływanie emocji, a przedstawianie rzetelnych informacji.

Media muszą przedstawić uchodźcom oczekiwania niemieckiego społeczeństwa. Muszą im uświadomić, że decydując się na życie w bezpieczeństwie i wolności w granicach Republiki Federalnej Niemiec oraz na przynależność do niemieckiej społeczności, konieczne jest, by szybko nauczyli się posługiwać językiem niemieckim. Tylko wtedy, gdy dziennikarze relacjonują, nie manipulując informacją, i jednocześnie nie wykorzystują problemów i negatywnych wydarzeń do skandalizowania, jest możliwe budowanie wzajemnego zaufania pomiędzy społeczeństwem i nowymi przybyszami.

\section{NIEMIECKA POLITYKA WOBEC MIGRANTÓW}

Emigracja w ostatnich pięciu latach nie doprowadziła do koniecznych, politycznych decyzji. Większość uchodźców nie przybyła do Niemiec z powodu prześladowań, lecz po to, aby polepszyć swoje perspektywy życiowe. Wobec tego niemiecka polityka stanęła w obliczu konieczności wypracowania stanowiska co do następujących kwestii: Jak traktować migrantów, którzy przybędą do Niemiec? Czy migranci otrzymają możliwość stworzenia sobie nowych warunków do życia w niemieckim społeczeństwie?

Na drugim szczycie dotyczącym uchodźców we wrześniu 2015 podjęto uchwałę w sprawie przyspieszenia procesu związanego z otrzymaniem azylu. Uchwała weszła w życie w listopadzie 2015 roku. W związku z tym zostały wyjaśnione 
niektóre podstawowe filary polityki azylowej, dokonano także wyraźnego podziału uchodźców na tych, którzy doświadczyli prześladowania politycznego oraz tych, którzy opuścili swój kraj z powodów gospodarczych. Tym samym dużo łatwiejsze będzie deportowanie osób, których wniosek o azyl został odrzucony. Należy podkreślić, że cały proces przebiegnie szybciej, jeśli ubiegający się o azyl pozostaną w pierwszym miejscu swojego pobytu do zakończenia postępowania. Kiedy wniosek o azyl zostanie odrzucony, prawo powinno być stosowane konsekwentnie, co oznacza, że urzędy są zobowiązane do tego, aby egzekwować obowiązek wyjazdu. Warto nadmienić, że jeżeli do Urzędu Federalnego (Das Bundesamt) wpłynie liczba wniosków o azyl uniemożliwiająca jego sprawne funkcjonowanie, wówczas wnioski te zostaną zatrzymane i starannie rozpatrzone. Należy pamiętać również o tym, że powinno się zaplanować odpowiednio dużo czasu na porady dla uchodźców występujących o rozpoczęcie postępowania w sprawie przyznania azylu.

Liczba krytycznych głosów w sprawie budowanej przez rząd polityki dotyczącej uchodźców zwiększyła się na początku października 2015 roku zarówno w mediach, jak i w partiach politycznych. Polityka niezdecydowanego i nierejestrowanego przyjmowania wszystkich uchodźców - jak w przypadku uchodźców wytrwale koczujących przed dworcem w Budapeszcie - była odbierana jako główny powód napływu uchodźców od początku września 2015 roku. Politycy z CDU i SPD zaczęli domagać się zmniejszenia liczby nowo przybywających, nie określając jednak jej górnej granicy. Na początku października 2015 roku premier Bawarii Horst Seehofer ogłosił że, jeśli okaże się to konieczne, rząd federalny zostanie postawiony przed trybunałem konstytucyjnym i zostaną podjęte własne środki bezpieczeństwa w przypadku braku bezzwłocznego podjęcia działań w celu ograniczenia przemieszczania się uchodźców ${ }^{22}$. Ta wypowiedź spotkała się z krytyką zarówno w opozycji, jak i koalicji rządowej ${ }^{23} .3$ stycznia 2016 roku Seehofer podał zaś w wywiadzie po raz pierwszy konkretną liczbę uchodźców, na jaką mógłby się zgodzić - ,ponad 200 tys. ludzi” rocznie ${ }^{24}$. Kanclerz Niemiec nazwała „zadaniem tego wieku” zlikwidowanie przyczyn napływu uchodźców ${ }^{25}$.

22 Flüchtlingskrise: Seehofer droht Merkel mit Verfassungsklage, w: www.spiegel-online.de 9.10.2015 (13.11.2015).

23 AFP mol: Horst Seehofer macht sich nur lächerlich, w: www.welt-online.de 10.10.2015 (13.11.2015).

24 Seehofer: bis zu 200.000 Flüchtlinge pro Jahr verkraftbar, w: www.deutschlandfunk.de 3.1.2016 (13.2.2016).

25 G. Bannas, Unerhörtes aus Berlin, w: www.faz.net 14.1.2016 (15.2.216). 


\section{SKUTKI KRYZYSU MIGRACYJNEGO}

\subsection{Budżet państwa}

Według oszacowań Organizacji Współpracy Gospodarczej i Rozwoju (Organisation for Economic Co-operation and Development - OECD) wydatki rządowe będą wyższe ze względu na kryzys uchodźczy w latach 2016-2017 o ok. 17 mld euro (0,5 proc. PKB). To stworzyłoby dodatkowy popyt ${ }^{26}$. Według obliczeń Instytutu dla Gospodarki Światowej (Institut für Weltwirtschaft) opieka nad uchodźcami będzie kosztować nawet 55 mld euro rocznie ${ }^{27}$.

Centrum Europejskiego Rozwoju Gospodarczego (Zentrum für Europäische Wirtschaftsförderung (ZEW) szacuje obciążenie długoterminowego budżetu państwa do ok. 40 mld euro, jeśli wydajność uchodźców nie będzie przekraczać efektywności pracy Niemców o niższych kwalifikacjach. Gdyby 60 proc. uchodźców osiągnęło wydajność osób z wykształceniem zawodowym, skutkowałoby to obciążeniem budżetu w granicach 113-218 mld euro. W pełni wykwalifikowani pracujący uchodźcy doprowadziliby do dodatniego salda w wysokości $20 \mathrm{mld}$ euro $^{28}$.

We wrześniu 2016 Instytut Gospodarki Światowej oszacował, że koszty związane z uchodźcami przebywającymi w Niemczech, które musi ponieść podatnik, na rok bieżący wyniosą $20 \mathrm{mld}$ euro. Obliczenia wykonane na podstawie ankiety przeprowadzonej wśród krajów związkowych wykazały, że będzie to 19,8 mld euro, natomiast 11,3 mld euro to kwota, jaką ponoszą gminy za opiekę nad uchodźcami, a rząd za dodatkowe usługi. Aby uniknąć wzrostu dopłat w 2017 - roku wyborczym - rząd chce dodatkowo przekazać 1,5 mld euro z funduszu zdrowia do $\mathrm{kas}^{29}$.

\subsection{Systemy spoleczne}

Hans-Werner Sinn, uwzględniając sytuację w Stanach Zjednoczonych, twierdzi, że imigracja większości nieznacznie wykwalifikowanych ludzi doprowadzi do nadmiernej podaży w tym segmencie rynku pracy, a zatem wynagrodzenie będzie spadać. Sytuację trzeba zatem nieznacznie złagodzić. Wyrównanie rozwoju demograficznego w pierwszej kolejności przez przyjazd imigrantów wydaje się wątpli-

${ }^{26}$ Konjunkturprogramme November 2015 - Deutschland, w: www.oecd-online.de 9.11.2015 (13.12.2015).

27 Top-Ökonom fordert Lohnsubventionen für Flüchtlinge, „Die Welt“ 15.12.2015, s. 10.

28 M. Schieritz, Arbeitsmarkt: Flüchtlinge kosten bis zu 400 Milliarden Euro, w: www.zeit-online. de 27.4.2016 (13.5.2016).

29 Krankenkassen skeptisch über zusätzliche Milliarden im Wahljahr, w: www.zeit-online.de 19.6.2016 (15.7.2016). 
wym rozwiązaniem. Tym sposobem do roku 2025 Niemcy musiałyby przyjąć 32 mln migrantów, a to byłoby niemożliwe bez zanegowania wartości zachodnich ${ }^{30}$. Należy liczyć się z tym, że przy migracji rzędu miliona osób w latach 2015-2016 migranci nigdy nie będą dobrze zintegrowani.

Pomoc i darmowe wyżywienie otrzymało w 2015 roku ok. 1,5 mln ludzi. Jednak ok. 250 tys. uchodźców mimo opieki w miejscach zamieszkania szukało dodatkowo darmowego jedzenia ${ }^{31}$.

Kiedy medyczna opieka uchodźców zostanie opłacona przez gminy na 15 miesięcy, będą oni mogli, dopóki nie wygenerują wystarczających dochodów, być przydzieleni poprzez pokrycie z zasiłku dla bezrobotnych ustawowego ubezpieczenia zdrowotnego do opieki zdrowotnej. Ponieważ państwowe wpłaty na ubezpieczenie zdrowotne dla przebywających na zasiłku dla bezrobotnych nie są wystarczające, inni ubezpieczeni muszą ponosić dodatkowe opłaty.

\subsection{Rynek pracy}

W związku z tym, że jedną z grup docelowych szeroko pojętej polityki zatrudnienia są migranci, jest ona częścią strukturalnej polityki integracji. Podobnie wygląda sytuacja w każdej ekonomicznej polityce, która zbliża się do gospodarki ogólnej i nadaje się do tego, aby zabezpieczyć i rozszerzyć zatrudnienie i jednocześnie politykę integracji dla migrantów. Silna gospodarka i rozwinięta polityka socjalna są dla udanej integracji zarówno całkiem ogólne, jak i stanowią jej ważne uwarunkowanie.

Najważniejszą kwestią dotyczącą wejścia uchodźców na niemiecki rynek pracy jest opanowanie języka niemieckiego. Prawie każdy zawód wymaga komunikacji, a więc posiadania umiejętności językowych przynajmniej na podstawowym poziomie. Dotyczy to przede wszystkim coraz silniej rozwijającej się w gospodarce branży usług. Szczególne znaczenie mają w tym kontekście zawodowe kursy językowe, zwłaszcza te, które pozwolą wypełnić luki na rynku pracy, np. w branży opiekuńczej.

Migranci są często zatrudniani na stanowiskach niezwiązanych z wyuczonym czy wykonywanym przez nich zawodem we własnym kraju, bądź też pozostają bezrobotni. Według oceny menedżerów personalnych możliwe jest zatrudnienie $\mathrm{w}$ anonimowym procesie aplikacyjnym $\mathrm{w}$ prawie wszystkich obszarach zatrudnienia. Brak informacji danych osobowych $w$ dokumentach aplikacyjnych nie jest problemem dla większości menedżerów personalnych.

\footnotetext{
30 Interview mit Hans-Werner Sinn, w: www.zeit-online.de 8.10.2015 (13.11.2015).

31 Tafeln rationieren Essen wegen Flüchtlingsandrang, w: www.welt-online.de 3.3.2016 (15.7.2016).
} 


\section{ZAKOŃCZENIE}

W powszechnej opinii konieczne jest pilne przemyślenie europejskiej polityki azylowej w obliczu kryzysu migracyjnego. Uchodźcy przybywają z marzeniem o bezpieczeństwie i często odmiennym od europejskiego rozumieniem godności i praw człowieka. Część z nich wywodzi się z krajów, w których chrześcijaństwo jest prześladowane prawem islamskim. Równość płci jest dla nich obca. To stwarza realne zagrożenie dla wartości bliskich kulturze Zachodu. Takie hasła jak: „obce wpływy”, ,islamizacja”, ,zagłada Europy” są zazwyczaj wyrażane z polemicznym zamiarem, wyrażają jednak wzrastającą niepewność co do trwałości porządku ustalonego zgodnie ze standardami zachodnioeuropejskimi. Rząd niemiecki musi zdać sobie z tego sprawę i jednocześnie odpowiedzieć na obawy swoich obywateli. Europejskie społeczeństwo nie boi się islamu, który nie zagraża spokojnemu współżyciü2 ${ }^{32}$ Lęk budzi islam, który zagraża ich bezpieczeństwu ${ }^{33}$. Konieczne jest zatem znalezienie drogi do otwartego dialogu i owocnej współpracy dla chrześcijan i muzułmanów ${ }^{34}$. Nie istnieje jednak żadna realna alternatywa ${ }^{35}$. Międzynarodowy dialog służy większemu wzajemnemu zrozumieniu, a tym samym ma ogromne znaczenie dla światowego pokoju ${ }^{36}$. Dlatego dialog należy rozumieć jako sposób skutecznego pojednania, najważniejszy element kultury pokoju i cywilizacji miłosierdzia ${ }^{37}$. Niech więc w Niemczech spotkania między muzułmanami i chrześcijanami tworzą podstawy dla wspólnego życia i pracy w solidarności i pokoju, by nasz świat mógł stać się światem dla wszystkich.

32 Por. G. Schweizer, Islam verstehen. Geschichte, Kultur und Politik, Klett-Cotta Verlag, Stuttgart 2016, s. 18-19.

33 Por. T. Jaap, ,, Alle Muslime sind... ” 50 Fragen zu Islam und Islamophobie, Verlag an der Ruhr, Mülheim an der Ruhr 2011, s. 150-152; M. Khorchide, Muslim sein in Deutschland, Verlag Herder GmbH, Freiburg im Breisgau 2016, s. 16.

34 Por. F. Sen, H. Aydin, Islam in Deutschland, Verlag C.H. Beck oHG, München 2002, s. 7; Ch.W. Troll, Muslime fragen, Christen antworten, Verlag Friedrich Pustet, Regensburg 2004, s. $10-13$.

35 Por. A.T. Khoury, Kommen Muslime in den Himmel? Gelangen Christen ins Paradies? Beiträge zum christlich-islamischen Dialog, Echter Verlag GmbH, Würzburg 2007, s. 117.

36 Por. A. Günthör, Sind alle Religionen gleich? Die Antwort Papst Benedikts XVI, fe-medienverlag GmbH, Kisslegg 2007, s. 72.

37 Por. A.T. Khoury, Kommen Muslime in den Himmel?, s. 7; F. Gülen, Was ich denke, was ich glaube, Verlag Herder GmbH, Freiburg im Breisgau 2014, s. 247; M. Khorchide, Islam ist Barmherzigkeit. Grundzüge einer modernen Religion, Verlag Herder GmbH, Freiburg im Breisgau 2012, s. 11. 


\section{Bibliografia}

AFP mol: Horst Seehofer macht sich nur lächerlich, w: www.welt-online.de 10.10.2015 (13.11.2015).

Bachner F., Notquartiere für Flüchtlinge in Berlin: Funktionäre fordern Räumungsplan für Sporthallen, „Der Tagespiegel“ 06.04.2016, s. 8.

Bannas G., Unerhörtes aus Berlin, w: www.faz.net 14.1.2016 (15.02.2016).

Die Arbeitsintegration von Flüchtlingen in Deutschland, w: www.bertelsmann-stiftungstudie 2015.de (13.12.2015).

Die meisten, die herkommen, denken nicht an Integration, w: www.welt-online. de 30.09.2015 (13.10.2015).

Der Tag: Anschläge auf Flüchtlingsheime nehmen drastisch zu, w: www.ntv. de 28.09.2015 (13.10.215).

Flüchtlinge durch Bildung integrieren, w: www.bundesministeriumfuerbildungund forschung.de 30.09.2015 (30.10.2015).

Flüchtlingskrise: Seehofer droht Merkel mit Verfassungsklage, w: www.spiegel-online.de 09.10.2015 (13.11.2015).

Freiwillige sind unentbehrlich, w: www.sueddeutsche.de 23.09.2015 (20.10.2015).

Gesetz zur Flüchtlingsunterbringung! Hamburg beschließt Beschlagnahme von Immobilien, w: www.spiegel-online.de 2.10.2015 (13.11.2015).

Gewaltwelle: BKA zählt mehr als tausend Attacken auf Flüchtlingsheime, w: www.spiegel-online.de 28.1.2016 (13.2.2016).

Gülen F., Was ich denke, was ich glaube, Verlag Herder GmbH, Freiburg im Breisgau 2014.

Günthör A., Sind alle Religionen gleich? Die Antwort Papst Benedikts XVI, fe-medienverlag GmbH, Kisslegg 2007.

Heckmann F., Integration von Migranten. Einwanderung und neue Nationenbildung, Springer Verlag, Wiesbaden 2015.

Heinzle Ch., Weydt E., Tausende Flüchtlinge als Schwarzarbeiter ausgebeutet, w: www.welt-online.de 30.8.2016 (30.9.2016).

Himmelrath A., Erstaufnahme in Turnhallen: Immerhin winterfest, w: www. spiegel-online.de 18.11.2015 (13.12.2015).

Holtkamp J., Flüchtlinge und Asyl. Herausforderung-Chance-Zerreißprobe, Lahn-Verlag, Kevelaer 2016.

Interview mit Hans-Werner Sinn, w: www.zeit-online.de 8.10.2015 (13.11.2015).

Jaap T., ,,Alle Muslime sind...” 50 Fragen zu Islam und Islamophobie, Verlag an der Ruhr, Mülheim an der Ruhr 2011.

Kermani N., Wer ist wir. Deutschland und seine Muslime. Mit der Kölner Rede zum Anschlag auf Charlie Hebdo, Verlag C.H. Beck oHG, München 2016.

Khorchide M., Islam ist Barmherzigkeit. Grundzüge einer modernen Religion, Verlag Herder GmbH, Freiburg im Breisgau 2012. 
Khorchide M., Muslim sein in Deutschland, Verlag Herder GmbH, Freiburg im Breisgau 2016.

Khoury A.T., Kommen Muslime in den Himmel? Gelangen Christen ins Paradies? Beiträge zum christlich-islamischen Dialog, Echter Verlag GmbH, Würzburg 2007.

Konjunkturprogramme November 2015 - Deutschland, w: www.oecd-online. de 9.11.2015 (13.12.2015).

Krankenkassen skeptisch über zusätzliche Milliarden im Wahljahr, w: www. zeit-online.de 19.6.2016 (15.7.2016).

Kriminalität: Furcht vor neu organisiertem Rechtsterrorismus, w: www.zeit-online.de 28.8.2015 (13.9.2015).

Leimgruber S., Feinde oder Freunde. Wie können Christen und Muslime miteinander umgehen, Lahn-Verlag, Kevelaer 2008.

Luft S., Die Flüchtlingskrise. Ursachen, Konflikte, Folgen, Verlag C.H. Beck oHG, München 2016.

Samir S.K., 100 Fragen zum Islam. Warum wir die Muslime nicht fürchten müssen, Sankt Ulrich Verlag, Augsburg 2009.

Schieritz M., Arbeitsmarkt: Flüchtlinge kosten bis zu 400 Milliarden Euro, w: www.zeit-online.de 27.4.2016 (13.5.2016).

Schweizer G., Islam verstehen. Geschichte, Kultur und Politik, Klett-Cotta Verlag, Stuttgart 2016.

Seehofer: bis zu 200.000 Flüchtlinge pro Jahr verkraftbar, w: www.deutschlandfunk.de 3.1.2016 (13.2.2016).

Sen F., Aydin H., Islam in Deutschland, Verlag C.H. Beck oHG, München 2002.

Spahn J. (red.), Ins Offene. Deutschland, Europa und die Flüchtlinge. Die Debatte. Verlag Herder GmbH, Freiburg im Breisgau 2015.

Stoldt T.-R., Diese Frau greift den deutschen Islam frontal an, w: www.welt-online.de 30.10.2015 (13.11.2015).

Tafeln rationieren Essen wegen Flüchtlingsandrang, w: www.welt-online.de 3.3.2016 (15.7.2016).

Thomas M., Land lockert Bauvorschriften für Flüchtlingsheime, w: www. hannoverscheallgemeinezeitung.de 11.11.2015 (15.12.2015).

Top-Ökonom fordert Lohnsubventionen für Flüchtlinge, „Die Welt“ 15.12.2015, s. 10.

Troll Ch.W., Muslime fragen, Christen antworten, Verlag Friedrich Pustet, Regensburg 2004.

Verfolgt in Deutschland, w: www.welt-online.de 27.9.2015 (15.10.2015).

Wo in Deutschland Christen verfolgt werden, w: www.zeit-online.de 29.7.2014 (15.8.2014). 


\section{Streszczenie}

Ludzie, którzy z różnych powodów musieli uciekać, otrzymają pomoc w Niemczech, ponieważ niemieckie społeczeństwo tego chce i ponieważ współczucie, i co za tym idzie, okazanie miłości drugiemu człowiekowi jest wpisane w chrześcijański obraz człowieka. Przyczyn ucieczki w pierwszej linii należy szukać w trudnej sytuacji krajów, w których od dawna zaostrza i pogłębia się kryzys humanitarny. Niemcy wydają się być podzieleni: Jedni palą mieszkania uchodźców, inni angażują się w pomoc dla nich, przynosząc ubrania, jedzenie i podejmując inne inicjatywy na miejscu. Szerokie pole ogólnej polityki pracy i jej metod zamyka w zasadzie migrantów jako grupę docelową i jest właściwie strukturalną polityką integracyjną. W Niemczech żyje także wiele ludzi przeciwstawiających się uchodźcom, gdyż sami obawiają się utraty własnego miejsca pracy. Tylko wtedy, gdy dziennikarze szczerze relacjonują i jednocześnie nie wykorzystują problemów i negatywnych wydarzeń do skandalizowania i własnych profitów, jest możliwe wzajemne zaufanie pomiędzy społeczeństwem i przybyszami. Istnieje zatem pilna potrzeba, aby znaleźć drogę do otwartego dialogu i owocnej współpracy dla chrześcijan i muzułmanów.

Słowa kluczowe: kryzys migracyjny, Niemcy, uchodźcy, integracja, media

German Migration Crisis and its Consequences

\section{Summary}

The people who must escape from their countries as a result of war receive help in Germany because this society is willing to provide it. It is also out of compassion and the desire of showing love to another person which is after all inscribed in the Christian concept of man. The reason why they leave their homeland is in the first place the difficult situation in their countries which has long exacerbated and deepened the humanitarian crisis. The Germans seem to be divided: some make assaults on refugees' housing, others are engaged in helping them, bringing clothes, food and taking part in various initiatives on the spot. The broad agenda of national labour policy with its methods in principle targets the migrants as a group and is actually a structural integration policy. In Germany there are also many citizens frowning upon the refugees because they are afraid of losing their workplaces. Only when the media honestly present the news and at the same time do not take advantage of the problems and the negative events to make their broadcast more appealing and increase the profits, it may possible to gain the mutual trust between the host society and the newcomers. Therefore, there 
is an urgent need to find a way to open the dialogue and the successful cooperation of Christians and Muslims.

Keywords: migration crisis, Germany, refugees, integration, mass media 